\title{
Tantangan Pariwisata pada Wilayah Perbatasan dalam Era Disrupsi Teknologi: Studi Kasus Regulasi Transportasi Online di Kota Batam, Kepulauan Riau
}

Indonesian Journal of Tourism and Leisure, 2020
Vol. 01 (2), 73-81
C The Journal, 2020
DOI: $10.36256 /$ ijtl.v1i2.102
https://journal.lasigo.org/index.php/IJTL
Article History
Received: September $10^{\text {th }}, 2020$
Revised: November $7^{\text {th }}, 2020$
Accepted: November $9^{\text {th }}, 2020$

\section{Cindy Andini}

Program Studi Ilmu Hubungan Internasional, FISIP, Universitas Maritim Raja Ali Haji. Tanjungpinang. Kep. Riau Email: andinic7@gmail.com

\section{Dhani Akbar}

Program Studi Ilmu Hubungan Internasional, FISIP, Universitas Maritim Raja Ali Haji. Tanjungpinang. Kep. Riau Email: akbardhani@umrah.ac.id

\begin{abstract}
One of the products of technological disruption which is currently becoming the prima donna in order to facilitate the public is an online transportation application. Payment is also made easy, namely using e Money. Until now, tourists in Batam have started relying on this application because it is considered easy and safe. This study uses descriptive qualitative methods that aim to explain the existing problems by providing answers to the problems raised. Descriptive qualitative research is a study in which the writer explains the phenomenon that is adapted to the concept and theory as supporting material for proof of writing. Even though it makes it easy and absorbs a lot of workforce, the fact that online transportation is still a controversy has caused chaos and unrest. What policies should be implemented? and how can Industry 4.0 increase competitiveness in this strategic area? The government as a regulator needs to make policies to organize the movement of this transportation so that the conducive situation desired by tourists can be realized.
\end{abstract}

Keywords: Technological Disruption; Online Transportation; Industry 4.0; Tourism; Regulation.

\begin{abstract}
ABSTRAK
Salah satu produk dari disrupsi teknologi yang sedang menjadi primadona adalah aplikasi transportasi online. Dalam rangka memudahkan masyarakat, aplikasi ini unggul dalam metode pembayaran dengan menggunakan e-Money. Saat ini wisatawan di Batam, mulai mengandalkan aplikasi ini karena dinilai mudah dan aman. Penelitian ini menggunakan metode kualitatif deskriptif, yang bertujuan agar dapat menjelaskan permasalahan yang ada dengan memberikan jawaban atas permasalahan yang dikemukakan. Walaupun memudahkan dan menyerap banyak tenaga kerja, faktanya transportasi online masih menjadi kontroversi yang menyebabkan kericuhan dan keresahan. Apa saja regulasi yang dikeluarkan Pemko Batam dalam menertibkan transportasi online? dan bagaimana agar industri 4.0 dalam peningkatan daya saing di kawasan strategis ini? Pemerintah sebagai regulator perlu untuk membuat kebijakan untuk menata pergerakan dari transportasi ini agar situasi kondusif yang diinginkan oleh wisatawan bisa terwujud.
\end{abstract}

Kata Kunci: Gangguan Teknologi; Transportasi Online; Industry 4.0; Pariwisata; Regulasi

Corresponding Author

Name : Cindy Andini

Email : andinic7@gmail.com 


\section{Pendahuluan}

Pembahasan kasus ini berfokus kepada wilayah pariwisata di wilayah Kota Batam, Kepulauan Riau. Beberapa tahun belakangan, Batam difokuskan pada sektor pariwisatanya (Mandalia, 2019), hal ini didukung dengan perbaikan infrastruktur di Kota Batam. Banyak jalan diperbesar dan juga penataan kota diperindah. Di tengah iklim investasi, Kota Batam dinilai mulai kurang menjanjikan karena seiring terjadinya konflik perburuhan dan dualisme kewenangan antara Badan Pengusahaan (BP) Batam serta Pemerintah Kota (Pemkot) Batam (Zaenuddin et al., 2018). Pemerintah pusat memberikan kewenangan kepada BP Batam dalam hal perizinan pusat. Sementara Pemkot Batam berwenang mengeluarkan izin daerah meskipun proses perizinan ada di bawah Pelayanan Terpadu Satu Pintu (PTSP). Kewenangan BP Batam antara lain menerbitkan izin prinsip Badan Koordinasi Penanaman Modal (BKPM), angka pengenal impor dari Kementerian Perdagangan, dan izin dari kementerian lain. Sedangkan Pemkot Batam menangani izin daerah seperti Izin Mendirikan Bangunan (IMB), domisili, tanda daftar perusahaan, dan izin-izin lingkungan (Kamilah, 2016).

Problematika investasi di Indonesia sangat kompleks, ketika pemerintah berupaya penuh dalam meningkatkan daya saing terutama agar dapat menarik investasi ke Indonesia. Salah satu upaya dan terobosan baru untuk peningkatan daya saing regional dan dinamika global serta mendorong tumbuhnya investasi, melalui Peraturan Pemerintah No. 46 Tahun 2007 tentang Kawasan Perdagangan Bebas dan Pelabuhan Bebas Batam, yakni menetapkan Batam sebagai kawasan Free Trade Zone (Kurniawan, 2017). Kota Batam dicanangkan untuk memiliki jalan tol. Sejak dulu Kota Batam sering kedatangan wisatawan dari Singapura dan Malaysia. Hal ini dikarenakan akses yang mudah dan dekatnya jarak Batam dengan kedua negara tersebut. Pemberlakuan Free Trade Zone membuat Kota Batam menjadi primadona bagi orang-orang yang senang berbelanja (Kurniawan, 2017).

Tantangan kepariwisataan di Kota Batam semakin kompleks, seiring dengan perkembangan Kota Batam yang mulai sibuk merubah haluan menjadi kota wisata. Kota Batam adalah sebuah kota yang heterogen (Tarwiyani et al., 2017). Berbagai macam keberagaman ada di Kota Batam. Kota Batam memiliki akses yang dekat dengan Singapura dan Malaysia dan beberapa negara lainnya (Supriono, 2017). Dengan demikian peningkatan perkembangan kepariwisataan menjadi hal yang mungkin untuk dilakukan. Tantangannya adalah, perubahan ini membutuhkan waktu yang tidak Sebentar. Dalam perjalanan proses perubahan, harus ada tindakan solutif dari pemerintah untuk menarik minat penunjung dari negara lain maupun domestic.

Dengan adanya transportasi online, sangat memudahkan bagi turis yang datang ke Batam. Turis bisa kemanapun mereka mau hanya dengan sebuah aplikasi, mereka bisa memperkirakan jarak dan harga saat akan berkeliling di Kota Batam. Belum lagi aplikasi transportasi online menyediakan layanan pijat, pengantaran makanan, pengisian pulsa dan lain sebagainya. Dengan segala kemudahan akses yang diberikan oleh aplikasi, diharapkan dapat membantu wisatawan yang ingin berkeliling dengan target meningkatkan ekonomi Kota Batam itu sendiri. Namun, dalam perkembangannya, transportasi online membutuhkan payung hukum. Tujuannya untuk memperkuat serta membuat kenyamanan disemua pihak. Payung hukum tersebut sudah disahkan. Namun ada kendala-kendala seperti dari faktor kultural. Maksud dari faktor kultural ialah adanya sikap masyarakat yang masih belum menerima keadaan perkembangan teknologi yang begitu pesat dari waktu ke waktu. Payung hukum mulai rampung dan disahkan pada bulan Maret 2019. Regulasi itu diatur dalam Peraturan Menteri Perhubungan Republik Indonesia Nomor PM 12 tahun 2019 tentang Perlindungan Keselamatan Pengguna Sepeda Motor. Peraturan tersebut digunakan untuk kepentingan masyarakat pada aspek keselamatan, kemitraan, suspeni dan biaya jasa. Peraturan ini juga terdapat pada Peraturan Menteri Perhubungan nomor 118 tahun 2018 tentang Penyelenggaraan Angkutan Sewa. Regulasi ini 
hadir sebagai tindakan solutif dan juga penengah dari pemerintah, terkait kendala-kendala yang dihadapi oleh penumpang, pengendara serta operator (Menteri Perhubungan Indonesia, 2018).

Pariwisata merupakan salah satu sumber perekonomian terbesar dalam suatu wilayah (Firdaus \& Tutri, 2017; Sukriah, 2014) meskipun di tengah iklim investasi yang menurun. Batam yang merupakan wilayah perbatasan memanfaatkan kepariwisataan sebagai sumber perekonomian wilayah. Batam merupakan wilayah strategis tempat berkunjungnya para wisatawan luar negeri yang didukung oleh kemudahan akses. Sehingga, perkembangan perusahaan transportasi online sangat menjanjikan karena memberikan kemudahan bagi para wisatawan.

\section{Literature Review}

Menurut Fees, ketika kita berdiskusi mengenai globalisasi, mestinya kita menyatakan bahwa unsur-unsur lokal bisa diterima dalam unsur global, bukan unsur global bisa diterima dalam unsur-unsur local (Ruslan, 2015). Hal ini diperkuat dalam sebuah pernyataan yang menyatakan bahwa "Endless flow between global and the local, in the process of globalization, local needs to meet the global". Sehingga dalam konstruksi sosialnya, akan berimplikasi juga kepada sosio-ekonominya. Menyatukan antara global sebagai core, dan lokal sebagai periphery yang di sana juga menyinggung mengenai diffusion dan differentiation.

Menurut Dahles unsur yang memiliki pengaruh dalam kegiatan pariwisata tidak hanya didominasi oleh perusahaan yang bergerak di bidang pariwisata dalam skala besar saja, namun juga perusahaan-perusahaan skala kecil juga memberikan pengaruh. Dalam artian, ketika roda perekonomian (parawisata) digerakkan sesuai dengan target capaian pemerintahan, tentu harus mampu melibatkan unsur terkecil sekalipun. Seperti yang dikatakan bahwa: Small scale tourism enterprises contribute a vital force in the Indonesian Tourism Sector or whether these enterprises simply absorb labour that would other wise be unemployed (Arianti, 2014).

Dalam kajian Hubungan Internasional, Revolusi Industri 4.0 menjadi topik hangat dan selalu diperbincangkan. Banyak negara yang sudah sangat siap menerima revolusi industri ini (Pusat Penelitian Badan Keahlian DPR RI, 2019). Dalam hubungan internasional, hal ini menjadi implikasi yang sangat positif. Memberikan kemudahan dalam pertukaran informasi, dan kecanggihan (Niko \& Samkamaria, 2019). Revolusi industri ini juga meningkatkan perekonomian jika di implementasikan dengan benar (Rahman \& Wartoyo, 2018). Contohnya saja transporatasi online seperti Gojek dan Grab. Peningkatan tersebut adalah karena pengembangan inovasi yang secara tidak sadar disebarkan melalui media. Yang dahulu tidak mungkin, sekarang bisa menjadi mungkin. Gojek bahkan sudah melebarkan sayapnya ke negara negara tetangga seperti Vietnam (Kristo, 2018). Hal ini tentu saja meningkatkan devisa negara dan mempererat hubungan negara yang terkait.

Terjadinya bisnis internasional menjadi tidak dapat dipungkiri (Minardi et al., 2020). Disrupsi teknologi sudah menjadi sorotan dari berbagai macam kalangan hingga membentuk lembaga-lembaga yang membahas bagaimana menerima disrupsi itu sendiri. Walaupun dapat dikatakan bahwa perkembangan ini merupakan hal positif, namun dalam satu dua aspek tetap ada hal negatifnya seperti informasi pribadi yang sangat mudah dilihat secara online dan juga percepatan informasi yang terkadang belum terfilter.

\section{Metodologi}

Penelitian ini menggunakan metode penelitian kualitatif deskriptif, yakni menjelaskan fenomena yang disesuasikan dengan konsep serta teori sebagai bahan pendukung dari pembuktian penulisan. Metode penelitian kualitatif deskriptif merupakan penjabaran dari hasil yang didapat dari penelitian yaitu berupa data dari beberapa sumber. Metode penelitian kualitatif berfokus pada ketajaman analisis. Penelitian kualitatif deskriptif merupakan sebuah penelitian dengan cara mengolah data empirik. Penelitian ini dijelaskan dengan cara deskriptif yaitu dijabarkan melalui 
pemecahan-pemecahan masalah secara lebih rinci. Indikator penelitian ini dijabarkan secara naratif dan analisisnya dikembangkan secara deskriptif. Penelitian kualitatif deskriptif ini lebih berfokus pada prosesnya daripada hasil dari pemecahan masalah. Penelitian ini berlokasi di Kota Batam-Provinsi Kepulauan Riau. Penelitian ini menggunakan teknik pengumpulan data primer dan sekunder. Data primer dilakukan melalui wawancara dan observasi langsung ke lapangan dengan beberapa stakeholder terkait dan juga menggunakan data sekunder melalui surat kabar online dan juga jurnal atau karya ilmiah lainnya. Teknik pengumpulan data pada penelitian ini menggunakan teknik wawancara dan observasi langsung.

\section{Hasil dan Pembahasan}

\subsection{Gambaran Umum Pariwisata dan Transportasi di Kota Batam}

Wilayah perbatasan mempunyai keunggulan tersendiri dari aspek kemudahan akses. Sehingga dapat mengurangi biaya perjalanan bagi turis asing. Secara geografis Kota Batam merupakan daerah transit Internasional yang memudahkan masukkan siapa (subjek) yang dimudahkan. Kota Batam memiliki beberapa objek wisata yang berpotensi untuk menarik wisatawan, baik domestik maupun mancanegara. Objek-objek wisata Kota Batam seperti; resort, pulau-pulau tropis, taman bermain Ocarina Batam Theme Park, Batam Forest Top, mall besar yang punya brand-brand ternama. Kesemuanya yang menjadi destinasi yang diinginkan oleh wisatawan luar negeri dan dalam negeri.

Kebutuhan dalam mobilisasi sangat dibutuhkan dalam dunia pariwisata di Kota Batam. Sehingga perkembangan perusahaan transportasi online sudah mulai menjamur di Kota Batam seiring perkembangan Technological Disruption di Kota Batam. Fenomena Technological Disruption ini menimbulkan polemik di Kota Batam, perusahaan transportasi online yang seharusnya membantu malah menimbulkan masalah di sana-sini.

Kehadiran transportasi online memang sangat terasa membantu para wisatawan yang berkunjung ke wilayah Kota Batam. Mengingat di tahun 2014, transportasi darat masih mengandalkan angkot, mini-bus, dan taksi pangkalan. Selain di bawah standar kelayakan operasional (angkot dan mini-bus), faktor keamanan menjadi perhatian utama masyarakat, mengingat dengan tingginya tingkat persaingan para pengemudi. Tidak jarang yang pengemudi melanggar tata tertib lalu lintas. Selain itu, untuk taksi pangkalan, dari segi harga, mematok tariff yang terbilang cukup tinggi. Jarak yang sebenarnya bisa dihitung menggunakan "argo", lebih cenderung diindahkan dan menggunkakan sistem "borongan" atau satu tarif jauh dekat. Hal ini bisa dibuktikan dengan adanya tarif tidak sampai $5 \mathrm{KM}$, namun wisatawan harus merogoh kocek hingga 60 ribu Rupiah.

Dua sisi mata uang, menilik transportasi daring dan konvensional ini, dimana seringkali terjadi gesekan antara pengemudi daring dan konvensional. Namun yang menarik adalah ketika permasalahan ini, terutama di kota-kota besar, sudah selesai? Mengapa Batam sebagai salah satu kota industri besar yang menjadi salah satu destinasi favorit wisatawan domestik hingga mancanegara enggan menyelesaikan masalah ini hingga ke akarnya. Padahal, bentrok seperti ini juga akan sangat berpengaruh terhadap kenyamanan dan keamanan berkendara para wisatawan.

Penyelesaian sengketa "wilayah" kedua belah pihak, sebenarnya dapat diselesaikan dengan langkah konkret oleh pemerintah sebagai regulator dan melalui perusahaan sebagai private sector. Bersepakat dalam sebuah konvensi yang bisa ditandatangani bersama dalam sususan kedudukan hukum yang jelas. Permasalahan pengemudi, dikembalikan kepada pihak perusahaan yang harus dapat memberikan sanksi tegas terhadap setiap pelanggaran kesepakatan. Pengertian disrupsi teknologi adalah sebuah kondisi dimana hal hal yang biasanya dikerjakan di dunia nyata, bisa dilakukan didunia maya (Prasetyo \& Trisyanti, 2019). Disrupsi teknologi berkaitan erat dengan industri 4.0. Dikatakan sebagai disrupsi teknologi adalah karena otomasi dan konektivitas disebuah bidang akan membuat pergerakan dunia industri dan persaingan kerja menjadi tidak 
selaras (Nurjani, 2019). Disrupsi teknologi menggeser industri atau produk yang kemudian akan membuat industri baru. Contohnya adalah sistem transportasi online yang sedang marakmaraknya.

Pengertian transportasi online itu sendiri adalah sebuah alat transportasi yang menerapkan teknologi dalam mencari penumpang, sistem pembayaran yang memudahkan pengguna teknologi tersebut. Contoh yang paling marak di Indonesia akhir-akhir ini adalah ojek online dan taksi online dari berbagai macam aplikasi, yaitu Gojek, Grab dan lain sebagainya. Hal ini sangat marak karena penggunaanya yang mudah dan sederhana yang disertai dengan harga yang lebih ekonomis dibandingkan dengan ojek maupun taksi konvensional.

Hal-hal semacam ini dapat dikatakan wajar, mengingat sekarang sudah memasuki era Industri 4.0. Era Industri 4.0 ini ditandai dengan banyaknya peningkatan teknologi seperti aplikasi, penerapan robot, artificial intelligent dan lain sebagainya. Implikasi dari perkembangan ini bisa dikatakan sangat baik, banyak kemudahan yang diberikan sebagai hasil dari perkembangan ini. Namun belum semua yang merasakan dampak positifnya. Contohnya saja kontroversi ojek konvensional dan ojek online yang dibahas saat ini.

Kemunculan transportasi online di Kota Batam itu sekitar tahun 2015 dan mulai marak pada tahun 2016 hingga sekarang (Batamnews, 2016). Transportasi online seperti Gojek dan Grab menjadi primadona yang selalu diandalkan oleh masyarakat karena mudah digunakan dan harganya relative terjangkau dibanding ojek konvensional. Disinilah kontroversi dimulai karena pada dasarnya ojek konvensional masih sangat banyak di kota Batam pada saat ini. Mereka menolak habis-habisan adanya ojek online, hingga menyebabkan perkelahian dan penurunan paksa penumpang yang menggunakan ojek online. Tidak jarang pula terjadi bentrok dibeberapa titik di Kota Batam. Bahkan pernah juga ojek konvensional menurunkan paksa orang yang dijemput oleh keluarganya karena dikira ojek online.

Pemerintah bahkan pernah menutup kantor Gojek karena belum memebuhi standar prosedur (Batampos.co.id, 2020). Hal itu memunculkan pro dan kontra di kalangan masyarakat. Dengan beberapa kejadian yang hampir selalu terjadi itu, menimbulkan keresahan warga setempat yang selalu khawatir jika naik transportasi online karena takut dicegat oleh sekelompok orang yang ternyata adalah sekumpulan ojek konvensional. Banyak sekali kejadian yang merugikan beberapa pihak. Padahal, tidak dapat dipungkiri Industri 4.0 akan terus berlanjut tanpa kita sadari.

Tabel 1. Jumlah Badan Usaha Angkutan Taksi Konvensional

\begin{tabular}{clc}
\hline No & \multicolumn{1}{c}{ Nama Badan Usaha } & $\begin{array}{c}\text { Jumlah } \\
\text { Armada }\end{array}$ \\
\hline 1 & Koperasi Citra Wahana & 312 \\
2 & PT. Erina Mandiri/Eks. Koperasi Bina Warga Pt & 81 \\
3 & Primkopad & 138 \\
4 & Primkoppal & 174 \\
5 & PT.Suluh & 122 \\
6 & Koperasi Pandu Wisata & 134 \\
7 & Kopra - OB & 272 \\
8 & Kopti & 200 \\
9 & KPTDS & 195 \\
10 & PT. Blue Bird & 75 \\
11 & CV. Manunggal Mandiri & 55 \\
12 & PT. Almi Transport & 63 \\
13 & KOPEBA & 170 \\
14 & KOPTIBA & 103 \\
15 & KOPETAB & 28 \\
16 & KOPTIS & 79 \\
17 & PT. Pinki & 108 \\
18 & PT. Doresindi & 50 \\
19 & Primkoppol & 188 \\
\hline
\end{tabular}

Sumber: Dinas Perhubungan Kota Batam. 2018 
Dengan banyaknya kontroversi ini, pemerintah akhirnya memberikan payung hukum kepada transportasi online. Payung hukum ini mulai rampung dan disahkan pada bulan Maret 2019 yang diatur oleh Peraturan Menteri Perhubungan Republik Indonesia Nomor PM 12 tahun 2019 tentang Perlindungan Keselamatan Pengguna Sepeda Motor Yang Digunakan Untuk Kepentingan Masyarakat. Kebijakan ini mengatur aspek tentang keselamatan, kemitraan, suspeni dan biaya jasa. Dengan adanya payung hukum ini menjadi respon pemerintah, yang sudah mulai menerima adanya transportasi online. Pemerintah menerima Revolusi Industri 4.0 yang sangat meningkat drastis pada saat ini. Walaupun bisa dikatakan pemerintah terlambat untuk merespon Revolusi Industri 4.0 itu sendiri. Namun adapula Peraturan Menteri Perhubungan nomor 118 tahun 2018 tentang Penyelenggaraan Angkutan Sewa Khusus. Kebijakan ini hadir sebagai tindakan solutif dan juga penengah dari pemerintah terkait kendala-kendala yang dihadapi oleh penumpang, pengendara serta operator dari transportasi online. Di dalam Peraturan Menteri nomor 118 tahun 2018 menjabarkan tentang beberapa syarat khusus perusahaan Angkutan Sewa Khusus. Beberapa diantaranya adalah mengurus izin penyelenggaraan Angkutan Sewa Khusus, lalu juga Perusahaan harus berbadan hukum Indonesia, dan juga mematuhi ketentuan Standar Pelayanan Minimal. Dari beberapa poin tersebut bisa kita simpulkan bahwa pemerintah mulai concern terhadap perkembangan teknologi dengan menyiapkan perangkat hukum untuk mengaturnya.

Hambatan yang dimiliki oleh transportasi online ini adalah kurangnya edukasi untuk masyarakat sehingga mereka belum bisa menerima keadaan dari technological disruption. Masyarakat belum mengetahui betapa pentingnya disrupsi teknologi ini sehingga masih terkesan tidak melek teknologi. Namun, walaupun payung hukum sudah rampung, bukan berarti para perusahaan transportasi online bisa berlaku semena-mena terhadap pelaku transportasi konvensional.

\subsection{SIAGA Transportation System Sebagai Alternatif}

Dalam perkembangannya, pariwsata di kawasan Kota Batam di bawah tahun 2015, masih menggunakan transportasi yang tidak sesuai standard. Tidak hanya itu transportasi pun memiliki banyak kendala dalam pelayanan yang dapat menumbuhkan kepuasan wisatawan baik domestic maupun mancanegara. Untuk itu, perlu adanya pembaruan dalam penetapan sistem standarisasi dalam trasnportasi untuk mendukung arus pariwisata di Kota Batam. Salah satu alterantif dalam penetapan itu dapat dihadirkan dalam bentuk SIAGA Transportation System, yaitu:

a. Safe, transportasi harus jelas drivernya, mereka daftar menggunakan Surat Keterangan Catatan Kepolisian (SKCK) yang dapat menjamin rasa aman pada wisatawan, memiliki nomor handphone yang terdaftar, identitas yang berlisensi.

b. Inclusive, transportasi harus memperhatikan kebutuhan dari wisatawan, salah satunya adalah wisatawan berkebutuhan khusus, sehingga bisa digunakan atau ramah untuk orang orang dengan disabilitas.

c. Accessible, transportasi harus bisa dijangkau dimanapun dan kapanpun. Pada kemajuan teknologi saat ini, tentu diperlukan sebuah fitur yang memudahkan segala bentuk kegiatan pariwisata. Salah satunya adalah aksesibilitas sebuah transportasi yang meliputi unsurunsur sebelumnya. Hal ini diperlukan agar perkembangan pariwisata juga dapat menyesuaikan diri dengan kemajuan teknologi dan era disrupsi teknologi era 4.0.

d. Green, transportasi memiliki usia atau batasan dalam penggunaan, agar pariwisata memiliki unsur sustainable dalam konteks environmental friendly. Maka penetapan batas ambang emisi gas. Misal kendaraan umum 5 tahun maksimal usianya.

e. Affordable, salah satu yang menjadi daya tarik wisatawan adalah harga dari jasa transportasi yang masuk ke dalam kategori terjangkau dan dalam batas kewajaran. Ini penting untuk menjadi focus utama oleh pemangku kebijakan. Karena, sebelum adanya transportasi online, sering dijumpai supir taksi konvensional yang memasang harga terlalu tinggi untuk jarak yang tidak terlalu jauh. 
Untuk mempromosikan pertumbuhan ekonomi yang berkelanjutan, inklusif dan berkelanjutan, pekerjaan penuh dan produktif dan pekerjaan yang layak untuk semua, masyarakat internasional bertujuan untuk mencapai pekerjaan penuh dan produktif dan pekerjaan yang layak untuk semua perempuan dan laki-laki, termasuk untuk para penyandang cacat upah yang sama untuk pekerjaan yang setara nilai. Akan bekerja untuk membuat kota dan pemukiman manusia inklusif, aman dan berkelanjutan. Untuk mewujudkan tujuan ini, negaranegara anggota diminta untuk memberikan akses ke sistem transportasi yang aman, terjangkau, dapat diakses, dan berkelanjutan untuk semua orang, meningkatkan keselamatan jalan, terutama dengan memperluas transportasi umum dengan perhatian khusus untuk kebutuhan mereka yang berada dalam situasi yang rawan, seperti penyandang cacat.

Selain itu, proposal tersebut menyerukan untuk menyediakan akses universal ke ruang-ruang yang inklusif dan mudah diakses, hijau, dan khusus untuk para penyandang disabilitas. Transportasi bagus bisa mendukung percepatan pembangunan daerah. Penerima manfaat masyarakat, wisatawan asing maupun domestic. Kemudahan transportasi akan membuat keinginan mereka untuk balik dan balik lagi, seperti halnya yang terjadi di Daerah Istimewa Yogyakarta.

\section{Kesimpulan}

Disrupsi teknologi adalah sebuah kondisi dimana hal-hal yang biasanya dikerjakan di dunia nyata, bisa dilakukan didunia maya. Pengertian transportasi online itu sendiri adalah sebuah alat transportasi yang menerapkan teknologi dalam mencari penumpang, sistem pembayaran yang memudahkan pengguna teknologi tersebut. Contoh yang paling marak di Indonesia akhir-akhir ini adalah ojek online dan taksi online dari berbagai macam aplikasi, yaitu Gojek, Grab dan sebagainay. Banyaknya kontroversi menyebabkan banyak kerugian materil dan inmateril kepada masyarakat. Hal ini memacu pemerintah untuk memberikan payung hukum terhadap transportasi online sebagai respon pemerintah terhadap penerimaan Revolusi Industri 4.0 yang diatur oleh Peraturan Menteri Perhubungan Republik Indonesia Nomor PM 12 tahun 2019 tentang Perlindungan Keselamatan Pengguna Sepeda Motor Yang Digunakan Untuk Kepentingan Masyarakat.

Dalam hubungan internasional, hal ini menjadi implikasi yang sangat positif. Memberikan kemudahan dalam pertukaran informasi, dan kecanggihan. Revolusi industri ini juga meningkatkan perekonomian jika di implementasikan dengan benar. Disrupsi teknologi tidak dapat dihindari karena akan ada dan terus beranjut hingga revolusi industri selanjutnya tiba. Hal ini benyak menguntungkan disegala sector dalam hubungan internasional, dari segi ikatan antar negara, percepatan informasi dan juga kecanggihan yang memudahkan segala sesuatu nya jika dilakukan dengan bijak.

Saran saya sebagai penulis, disrupsi teknologi jangan dijadikan sebagai alasan untuk terlambat maju, adanya perkembangan melalui Revolusi Industri 4.0 harusnya diterima dengan baik tanpa harus mengatakan bahwa dengan adanya revolusi ini akan menghilangkan budaya setempat. Hal semacam ini harus ditanggapi dan terima secara bijaksana. Perkembangan zaman di era seperti ini tidak akan berhenti karena akan ada terus menerus jadi kita harus membuka diri dalam menerima hal baru secara bijak untuk menjadi yang lebih baik lagi. Semestinya, permasalahan seperti pembagian wilayah kerja dan jangkauan, menjadi porsi yang bisa diatur oleh pembuat kebijakan. Seperti di beberapa kota besar lain di Indonesia, mereka telah mampu mengatur dan bahkan ada beberapa yang bahkan bisa bekerja sama. Paling utama, misalkan permasalahan titik jemput. Jika hal sepele semacam ini sudah settled, maka kericuhan tidak akan terulang kembali. Konsep dasar pada pembangunan pariwisata merujuk kepada situasi yang kondusif dan memberikan rasa aman kepada seluruh wisatawan yang akan berkunjung. Jika rasa aman sudah didapatkan, maka secara tidak langsung akan berpengaruh terhadap pariwisata dan peningkatan kunjungan wisatawan. 


\section{Acknowledgment}

Penulis berterimakasih banyak kepada pihak-pihak yang berkenan memberikan informasi, baik melalui wawancara maupun melalui data sekunder.

\section{Funding}

Penelitian ini merupakan penelitian mandiri yang tidak memiliki funding

\section{Conflicts of Interest}

Penulis menyatakan bahwa tidak terdapat conflict of interest dalam tulisan ini.

\section{Referensi}

Arianti, D. (2014). Pengaruh Sektor Parawisata terhadap Perekonomian dan Keruangan Kota Bukittinggi (Pendekatan Analisis Input Output). Jurnal Wilayah Dan Lingkungan, 2(3), 183196.

Batamnews. (2016). Go-Jek Beroperasi di Batam? Batamnews.Co.Id.

Batampos.co.id. (2020). Setiap Hari Terjadi Bentrok Taksi Online dan Konvensional di Batam. Batampos.Co.Id.

Firdaus, F., \& Tutri, R. (2017). Potensi Pengembangan Ekowisata Di Nagari Kotobaru, Kecamatan X Koto, Kabupaten Tanah Datar, Sumatera Barat. Jurnal Kawistara, 7(2), 115206. https://doi.org/10.22146/kawistara.13570

Kamilah, E. (2016). Pekan Ini Pemerintah Bahas Tumpang Tindih Pengurusan Izin Investor Batam. Kbr.Id.

Kristo, F. Y. (2018). Ekspansi Thailand dan Vietnam, Go-Jek Ganti Nama. Detik.Com.

Kurniawan, W. (2017). Free Trade Zone Sebagai Salah Satu Wujud Implementasi Konsep Disentralisasi. Jurnal Selat, 4(2), 160-189.

Mandalia, S. (2019). Perencanaan dan Pengembangan Destinasi Pariwisata Batam Perlu Diperjelas. Batamnews.Co.Id.

Menteri Perhubungan Indonesia. (2018). Peraturan Menteri Perhubungan Republik Indonesia tentang Penyelenggaraan Angkutan Sewa Khusus.

Minardi, A., Taufik, T., Afriantari, R., \& Hasanah, N. U. (2020). Indonesian Tourism Diplomacy to India. Indonesian Journal of Tourism and Leisure, 1(1), 1-13. https://doi.org/10.36256/ijtl.v1i1.83

Niko, N., \& Samkamaria. (2019). Terminal Barang Internasional (TBI) dalam Konteks Pembangunan Ekonomi Masyarakat di Perbatasan. Indonesian Journal of Religion and Society, 1(2), 104-114. https://doi.org/10.36256/ijrs.v1i2.65

Nurjani, N. P. S. (2019). Disrupsi industri 4.0; Implementasi, Peluang dan Tantangan Dunia Industri indonesia. Vastuwidya, 1(2), 23-32.

Prasetyo, B., \& Trisyanti, D. (2019). Revolusi Industri 4.0 dan Tantangan Perubahan Sosial. Revolusi Industri 4.0 Dan Tantangan Perubahan Sosial, 22-27.

Pusat Penelitian Badan Keahlian DPR RI. (2019). Pusat Penelitian Badan Keahlian DPR RI Berkelanjutan (C. M. Firdausy, A. Suryana, R. Nugroho, \& Suhartoko (eds.)). Pusat Penelitian Badan Keahlian DPR RI.

Rahman, H. Y., \& Wartoyo. (2018). Implementasi Produksi dalam Menghadapi Revolusi Industri (Studi Pada Provider di Indonesia). Profit: Jurnal Kajian Ekonomi Dan Perbankan, 2(2), 85-106.

Ruslan, I. (2015). Penguatan Ketahanan Budaya dalam Menghadapi Derasnya Arus Budaya Asing. Jurnal Tapis, 11(1), 1-19.

Sukriah, E. (2014). Parawisata Sebagai Sektor Unggulan Kota Bandung Tourism as Potential Sector in Bandung. Jurnal Manajemen Resort \& Leisure, 11(1), 65-74.

Supriono. (2017). Analisis Deskripsi Potensi Pariwisata Kota Batam dalam Rangka Menjaring Wisatawan Mancanegara. Jurnal Pariwisata Terapan, 1(2), 97-106. https://doi.org/10.22146/jpt.30150

Tarwiyani, T., Arnesih, \& Hutagaol, N. M. (2017). Fenomena Pasar Kaget di Kota Batam Tahun 1980-2015 (Sebuah Tinjauan Historis). Dimensi, 6(1), 48-62. 
Zaenuddin, M., Kumorotomo, W., Saleh, S., \& H. Hadna, A. (2018). Dualisme Kelembagaan antara Pemerintah Kota dan Badan Pengusahaan Batam Serta Dampaknya terhadap Kinerja Perekonomian di Kota Batam. Journal of Applied Business Administration, 1(2), 219231. https://doi.org/10.30871/jaba.v1i2.613 